\title{
Analisis Karakteristik Sumur Bor Sebagai Sumber Air Tanah pada Daerah Batu Karang dan Tandus
}

\author{
I Nengah Simpen ${ }^{1}$, Rina Dwi Indriana ${ }^{2}$, dan Sorja Koesuma ${ }^{3}$ \\ ${ }^{1}$ Jurusan Fisika, Fakultas MIPA, Universitas Udayana, Denpasar \\ ${ }^{2}$ Jurusan Fisika, Fakultas Sains dan Matematika, Universitas Diponegoro, Semarang \\ ${ }^{3}$ Program Studi Fisika, Fakultas MIPA, Universitas Sebelas Maret, Surakarta \\ Email: simpen.nengah@yahoo.com, rinadwiindriana@lecturer.undip.ac.id, sorja@staff.uns.ac.id
}

\begin{abstract}
Research on the characteristic analysis of boreholes has been carried out. This study is an example of research on the analysis of the characteristics of boreholes in rocky and barren areas. The research took an example at the Udayana University Hospital well located in Jimbaran Badung Bali. Analysis performed well efficiency (Ew), well development factor (Fd), well repair (C) and optimum discharge (Qopt). The results showed that based on the results of geoelectric measurements, the drilled well had aquifers. The well constructed is an efficient well with an efficiency level of $84.71 \%$. This means it is very efficient for water uptake. The well has a develop factor of 0.077864 days $/ \mathrm{m}^{3}$. This means that the well is very good to be developed. Value $\mathrm{C}=28994.2$. This means that if the well has a problem, for example, the discharge decreases, it is difficult for the well to return to its original state. The average density ( $\mathrm{Sc}$ ) obtained: $0.0196908 \mathrm{~m}^{2} / \mathrm{s}$, this value is greater than 0.005 . This means that the well has high productivity. The optimum discharge $\left(Q_{\text {opt }}\right)=0.00782 \mathrm{~m}^{3} / \mathrm{s}=28.152 \mathrm{~m}^{3} /$ hour. Optimum dropdown $\left(\mathrm{S}_{\text {wopt }}\right)=2.17 \mathrm{~m}$. It appears that there is a limited quantity of water reserves. The well test with constant discharge $\left(0.00328 \mathrm{~m}^{3} / \mathrm{s}\right)$ has been carried out for 7.5 hours. This means that $88.56 \mathrm{~m}^{3}$ of water has been taken, but the well only experiences a constant decrease in the water level of $22.2 \mathrm{~cm}$.
\end{abstract}

Keywords: bore well, groundwater, rocky, barren

\section{ABSTRAK}

Telah dilakukan penelitian tentang analisis karakteristik sumur bor. Penelitian ini merupakan suatu contoh penelitian tentang analisis karakteristik sumur bor di daerah batu karang dan tandus. Penelitian mengambil contoh di sumur RSPTN Universitas Udayana berlokasi di Jimbaran Badung Bali. Analisis yang dilakukan efisiensi sumur (Ew), faktor pengembangan sumur ( $F d$ ), perbaikan sumur (C) dan debit optimum $\left(\mathrm{Q}_{\mathrm{opt}}\right)$. Hasil penelitian didapatkan bahwa berdasarkan hasil pengukuran geolistrik, pada sumur bor memang ada akuifer. Sumur yang dibikin termasuk sumur yang efesien dengan tingkat efisiensi $84,71 \%$. Ini berarti sangat efesien untuk pengambilan air. Sumur memiliki faktor pengembang 0,077864 hari $/ \mathrm{m}^{3}$ Ini berarti sumur sangat baik untuk dikembangkan. Nilai C = 28994,2. Ini berarti apabila sumurnya ada kendala misalnya debitnya mengecil, maka sumur sulit dikembalikan menjadi seperti semula. Kapasitas jenis (Sc) rata-rata didapat: $0,0196908 \mathrm{~m}^{2} / \mathrm{s}$, nilai ini lebih besar dari 0,005 . Ini berarti sumur memiliki produktifitas tinggi. Debit optimum $\left(\mathrm{Q}_{\text {opt }}\right)=0,00782 \mathrm{~m}^{3} / \mathrm{s}=28,152$ $\mathrm{m}^{3} / \mathrm{jam}$. Drowdown optimum $\left(\mathrm{Sw}_{\mathrm{opt}}\right)=2,17 \mathrm{~m}$. Nampak bahwa adanya keterbatasan kuantitas cadangan air. Uji sumur dengan debit konstan $\left(0,00328 \mathrm{~m}^{3} / \mathrm{s}\right)$ telah dilakukan selama $7,5 \mathrm{jam}$ ini berarti air sumur telah diambil $88,56 \mathrm{~m}^{3}$, tetapi sumur hanya mengalami penurunan permukaan air sebesar $22,2 \mathrm{~cm}$ secara konstan.

Kata kunci: sumur bor, air tanah, batu karang, tandus 


\section{PENDAHULUAN}

Permasalahan sumber daya air, termasuk air tanah terdiri dari empat hal, yaitu jumlah yang tidak cukup, kualitas yang buruk, sebaran spasial yang tidak merata dan ketersediaannya tidak sepanjang waktu ${ }^{[1]}$. Tingkat permasalahan tersebut sangat tergantung dengan karakteristik wilayah seperti kondisi akuifer, ekologi bentang lahan, neraca air dan aktivitas manusia. Oleh karenanya analisis potensi sumber air menjadi sangat penting ${ }^{[1]}$. Air tanah tidak menjamin keberadaannya merata dalam ruang dan waktu ${ }^{[2]}$.

Salah satu cara untuk mendapatkan air tanah adalah dengan cara membuat sumur bor. Kepastian jumlah air yang dapat diambil dalam suatu sumur bisa dilakukan uji analisis karakteristik sumur dengan metode Step Drow Down test. Metode ini bekerja dengan cara melakukan pemompaan air sumur dengan debit bertingkat dalam kurun waktu tertentu, kemudian dicatat debit air yang diambil $(\mathrm{Q})$ dan penurunan muka air $\left(\mathrm{S}_{\mathrm{w}}\right)$. Berdasarkan kedua besaran ini didapatkan jumlah air yang dapat dambil $\left(\mathrm{Q}_{\mathrm{opt}}\right)$ dalam sumur tersebut.

Kepastian posisi sumber air tanah (akuifer) dapat dipakai bantuan metode geolistrik ${ }^{[3-7]}$. Metode ini bekerja berdasarkan arus listrik DC dengan frekwensi rendah. Pelaksanaannya dengan cara menginjeksikan arus listrik ke dalam tanah, kemudian diukur kuat arus yang diinjeksikan (I) dan beda potensial yang ditimbulkan (V), sehingga bisa dihitung resistivitas batuan. Namun resistivitas yang didapat berupa resistivitas semu. Untuk mendapatkan resistivitas riil, data dianalisis dengan program Res2divn. Hasil yang didapat berupa peta kontur penampang resistivitas lintasan pengukuran sehingga mendapatkan gambaran umum resistivitas batuan di lokasi pengukuran. Berdasarkan peta kontur ini dapat ditafsirkan posisi akuifer. Metode geolistrik telah terbukti berhasil dalam survey air tanah ${ }^{[8]}$ Penelitian dapat dilakukan dengan berbagai kofigurasi seperti konfigurasi. Wenner, Schlumberger, WennerSchlumberger, dan dipol-dipol. Konfiguasi mana yang akan dipakai hasilnya relatif sama.

Rumah Sakit Universitas Udayana merupakan satu-satunya Rumah Sakit Perguruan Tinggi Negeri (RSPTN) di Bali yang terletak di daerah Jimbaran Kuta Selatan Bali. Secara geografis terletak pada 8,7912635 LS, 115,1737306 BT dan ketinggian $44 \mathrm{~m}$ dpl. Formasi batuan di daerah ini merupakan formasi selatan terutama batugamping dan terumbu, setempat napal, sebagian berlapis, terhablur ulang dan berfosil ${ }^{[1]}$. Secara hidrogeologi terletak di daerah cekungan air tanah Nusa Dua ${ }^{[10]}$, dengan rata-rata curah hujan 1500-2000 $\mathrm{mm}^{[11]}$, jumlah imbuhan air tanah bebas $38.000 .000 \mathrm{~m}^{3} / \operatorname{tahun}^{[10]}$. Batu karang dan batu vulkanik yang berpori, juga dapat berfungsi sebagai akuifer. Akuifer jenis ini cadangan airnya sangat sedikit ${ }^{[12]}$. Sedikitnya seberapa?, belum jelas kuantifikasinya. RSPTN Universitas Udayana mengandalkan sumur bor sebagai sumber air. Melihat keadaan daerahnya seperti ini, maka sumur bor di RSPTN Universitas Udayana perlu kiranya dianalisis karakteristiknya sehingga dapat memberikan gambaran keadaan sumber airnya. Penelitian ini merupakan suatu contoh penelitian tentang analisis karakteristik sumur bor di daerah batu karang dan tandus. Penelitian dilakukan dengan cara menganalisis karakteristik sumur bor yang meliputi efisiensi sumur (Ew), faktor pengembangan sumur $(\mathrm{Fd})$, perbaikan sumur (C) dan debit optimum $\left(\mathrm{Q}_{\text {opt }}\right)^{[13][14]}$, sehingga penelitian ini berjudul Analisis Karakteristik Sumur Bor Sebagai Sumber Air Tanah pada Daerah Batu Karang dan Tandus. 


\section{METODE PENELITIAN}

Secara skema, metode penelitian dapat digambarkan seperti Gambar 1.

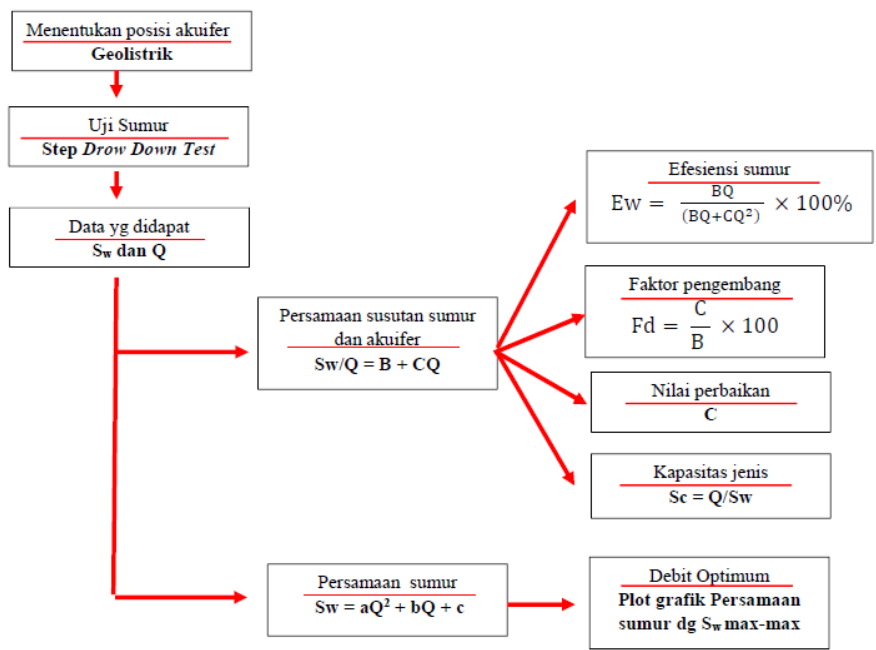

Gambar 1. Skema Metode Penelitian

Posisi akuifer dicari dengan metode geolistrik konfigurasi Wenner. Pengolahan data memakai program Res2divn. Karakteristik akuifer serta kemampuan sumur dalam memproduksi air, diperoleh dengan cara melakukan uji sumur. Parameter karakteristik sumur yang diuji meliputi efisiensi sumur $(\mathrm{Ew})$, faktor pengembangan sumur $(\mathrm{Fd})$, perbaikan sumur $(\mathrm{C})$ dan debit optimum $\left(\mathrm{Q}_{\mathrm{opt}}\right)^{[13][14]}$. Metode yang dipakai dalam uji sumur adalah metode step drawdown test ${ }^{[4][15] .}$

Langkah-langkah yang dikerjakan untuk mendapatkan parameter karakteristik sumur adalah sebagai berikut ${ }^{[12]}$ :

Pertama berdasarkan data surutan sumur ( $\mathrm{Sw}$ ) dan debit pemompaan $(\mathrm{Q})$, dibuat hubungan antara Sw/Q dengan $\mathrm{Q}$ dalam bentuk regresi linier sehingga didapatkan persamaan:

$$
\mathrm{Sw} / \mathrm{Q}=\mathrm{B}+\mathrm{CQ}
$$

Persamaan (1) dikenal dengan Persamaan Susutan Sumur dan Akuifer yang menunjukkan besarnya penurunan permukaan air saat pemompaan. B koefisien susut akuifer, $\mathrm{C}$ koefisien susut sumur dan Q debit pemompaan.

Kedua cari hubungan antara Sw dengan Q dalam bentuk regresi kuadratis yang menunjukkan hubungan antara debit pemompaan dengan penurunan permukaan air di dalam sumur. Bentuk persamaannya seperti persamaan (2) di bawah:

$$
\mathrm{Sw}=\mathrm{aQ}^{2}+\mathrm{bQ}+\mathrm{c}
$$

Sw penurunan permukaan air, Q debit sedangkan a, b, c konstanta. Persamaan (2) dikenal dengan Persamaan Sumur.

Langkah-langkah yang dikerjakan untuk menghitung parameter karakteristik sumur adalah sebagai berikut: 


\section{Metode analisis efisiensi sumur (Ew)}

Efisiensi sumur dihitung dengan menggunakan persamaan ${ }^{[4]}$.

$$
\mathrm{Ew}=\frac{\mathrm{BQ}}{\left(\mathrm{BQ}+\mathrm{CQ}^{2}\right)} \times 100 \%
$$

Ew: efisiensi sumur, Q: debit pemompaan, B: koefisien susut akuifer dan C: koefisien susut sumur. Sumur dikatakan efisien apabila memiliki Ew lebih besar atau sama dengan $50 \%$ [14].

\section{Metode analisis faktor pengembang (Fd) sumur}

Faktor pengembang didapat dengan cara membandingkan antara koefisien susut sumur (C) dan koefisien susut akuifer (B) ${ }^{[16]}$.

$$
\mathrm{Fd}=\frac{\mathrm{C}}{\mathrm{B}} \times 100
$$

Fd: faktor pengembang, B: koefisien susut akuifer dan C: koefisien susut sumur.

Kriteria Fd sebagai berikut: ${ }^{[16]}$

Tabel 1. Kriteria Nilai Fd

\begin{tabular}{ll}
\hline $\mathrm{Fd}\left(\right.$ hari $\left./ \mathrm{m}^{3}\right)$ & Kelas \\
\hline$<0,1$ & Sangat Baik \\
$0,1-0,5$ & Baik \\
$0,5-1$ & Sedang \\
$>1$ & Jelek \\
\hline
\end{tabular}

\section{Metode analisis nilai perbaikan sumur (C)}

Besarnya nilai $\mathrm{C}$ pada persamaan susutan sumur dan susutan akuifer menunjukkan kemungkinan perbaikan sumur dengan kriteria: ${ }^{[16]}$

Tabel 2. Kriteria Nilai C

\begin{tabular}{ll}
\hline $\mathrm{C}\left(\mathrm{menit}^{2} / \mathrm{m}^{5}\right)$ & Kondisi Sumur \\
\hline$<0,5$ & Baik \\
$0,5-1$ & Mengalami sedikit penyumbatan \\
$1-4$ & Penyumbatan di beberapa tempat \\
$>4$ & Sulit dikembalikan seperti semula \\
\hline
\end{tabular}

\section{Metode analisis kapasitas jenis sumur (Sc)}

Kapasitas jenis (Sc) merupakan gambaran kasar jumlah air yang dapat diproduksi oleh sumur. Nilai ini sangat tergantung dari debit pemompaan $(Q)$ dan penurunan permukaan air (Sw), yaitu:

$$
\mathrm{Sc}=\mathrm{Q} / \mathrm{Sw}
$$

Kriteria Sc sebagai berikut: ${ }^{[16]}$

Tabel 3. Kriteria Nilai Sc

\begin{tabular}{cl}
\hline Sc $\left(\mathrm{m}^{2} / \mathrm{s}\right)$ & Produktivitas Sumur \\
\hline$>5.10^{-3}$ & Tinggi \\
$5.10^{-3}-5.10^{-4}$ & Sedang \\
$5.10^{-4}-5.10^{-5}$ & Rendah \\
$5.10^{-5}-5.10^{-6}$ & Sangat rendah \\
$<5.10^{-6}$ & Dapat diabaikan \\
\hline
\end{tabular}




\section{Metode analisis debit optimum ( $\left.\mathbf{Q}_{\text {opt }}\right)$}

Debit optimum pemompaan berarti air sumur dapat diambil sebanyak-banyaknya, tetapi posisi pompa masih dalam batas aman secara teknik. Perhitungan debit optimun dengan bantuan plot grafik dengan langkah-langkah sebagai berikut. Pertama setelah didapatkan persamaan sumur (Persamaan 2) cari nilai debit maksimum $\left(\mathrm{Q}_{\max }\right)$ dengan memasukkan nilai susutan maksimum ( $\left.\mathrm{Sw}_{\max }\right)$ pada persamaan sumur (Persamaan 2). Nilai susutan maksimum $\left(\mathrm{Sw}_{\max }\right)$ adalah $\mathrm{Sw}$ maksimum yang dimungkinkan tetapi pompa masih dalam batas aman secara teknis. Kedua cari persamaan $\mathrm{Sw}_{\max \text {-max }}$ dengan memasukkan nilai $\mathrm{Sw}_{\max }$ dan $\mathrm{Q}_{\max }$. Nilai $\mathrm{Q}_{\text {opt }}$ didapat dengan syarat batas $\mathrm{Sw}_{\max \text {-max }}=\mathrm{Sw}$ atau perpotongan grafik Persamaan 2 dengan Persamaan $S_{\text {max-max }}$. Secara grafik dapat digambarkan sebagai berikut ${ }^{[4]}$.

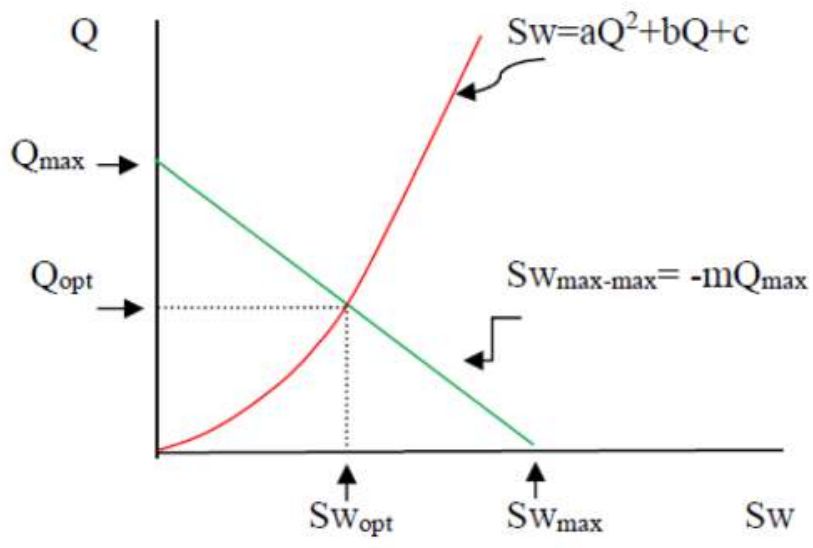

Gambar 2. Grafik Penentuan Debit Optimum (Q $\left.\mathrm{Q}_{\mathrm{opt}}\right)$

\section{HASIL DAN PEMBAHASAN}

\section{Kondisi geologi daerah penelitian}

Penelitian dilakukan di daerah Jimbaran Kabupaten Badung Bali. Daerah ini merupakan daerah kakinya pulau Bali. Daerah ini terdiri dari batu gamping dan tadus.

\section{Hasil Pengukuran dengan metode geolistrik}

Pengujian geolistrik dilakukan pada lintasan seperti dalam gambar berikut. Panjang lintasan 230,30 m. Posisi pengukuran dan hasil pengukuran yang telah dianalisis dapat dilihat pada gambar berikut.

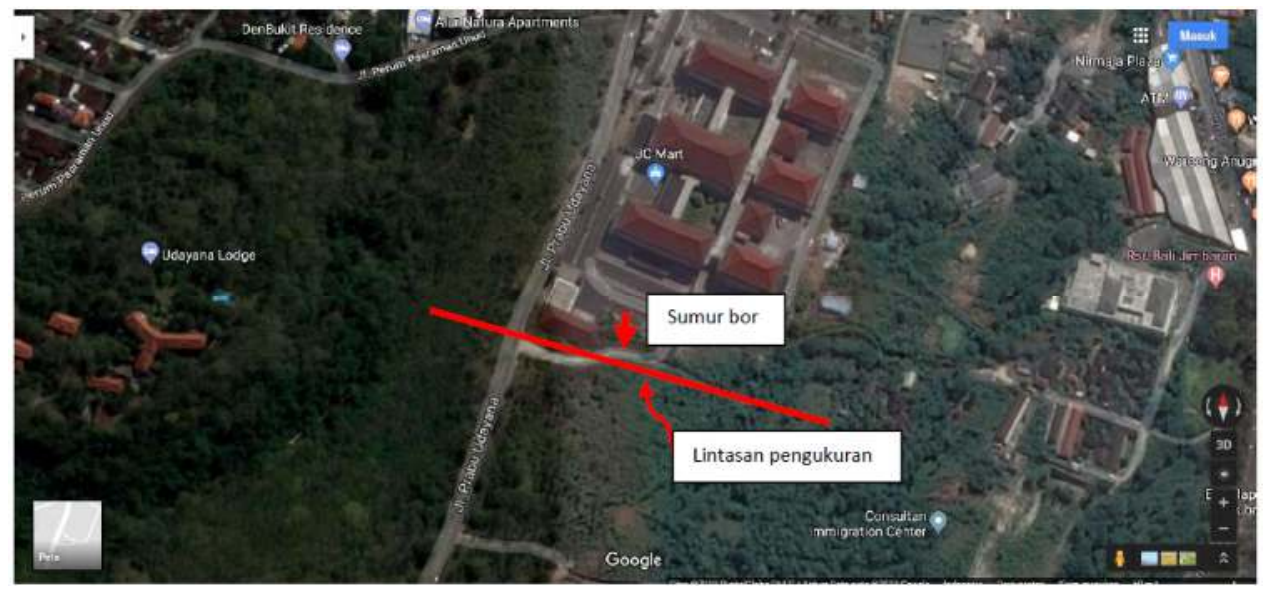

Sumber: https:/www.google.com/maps/@-8.7909494,115.173785,370m/data=!3m1!1e3

Gambar 3. Denah Pengukuran 


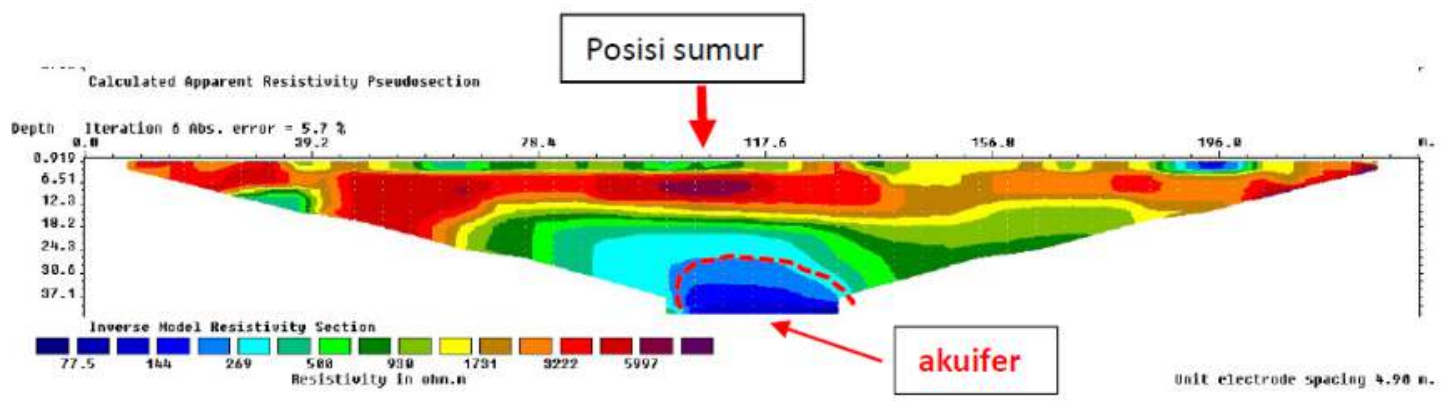

Gambar 4. Kontur Resistivitas Lintasan Pengukuran

Nampak bahwa adanya variasi resistivitas batuan di sekitar sumur dari 66,36 $\Omega . m-13037$ $\Omega . m$. Pada kedalaman $25 \mathrm{~m}$ di tengah-tengah lintasan pengukuran, nampak adanya resistivitas rendah $(77,5 \Omega . \mathrm{m})$ yang diduga sebagai akuifer. Nampak bahwa posisi sumur bor tidak tepat di tengah akuifer tetapi masih mengenai akuifer. Nampak pula bahwa tidak disemua tempat terdapat akuifer seperti yang dijelaskan oleh Cahyadi dkk..$^{[1]}$

\section{Hasil uji sumur}

Pada lokasi penelitian telah terpasang pompa berdaya besar dengan kekuatan 7500 Watt dengan debit maksimum $14 \mathrm{~m}^{3} / \mathrm{jam}$. Metode yang digunakan adalah Metode Step Drow Down Test. Debit pemompaan dilakukan dalam 4 tahap. Pencatatan dilakukan setiap 15 menit. Kedalaman permukaan air dianggap konstan apabila telah mencapai satu jam tidak ada penurunan, sehingga pengukuran dihentikan dan dilanjutkan dengan debit berikutnya. Data debit bertahap dan data penurunan permukaan air inilah yang dianalisa. Berikut diberikan foto saat melakukan pengukuran uji sumur.

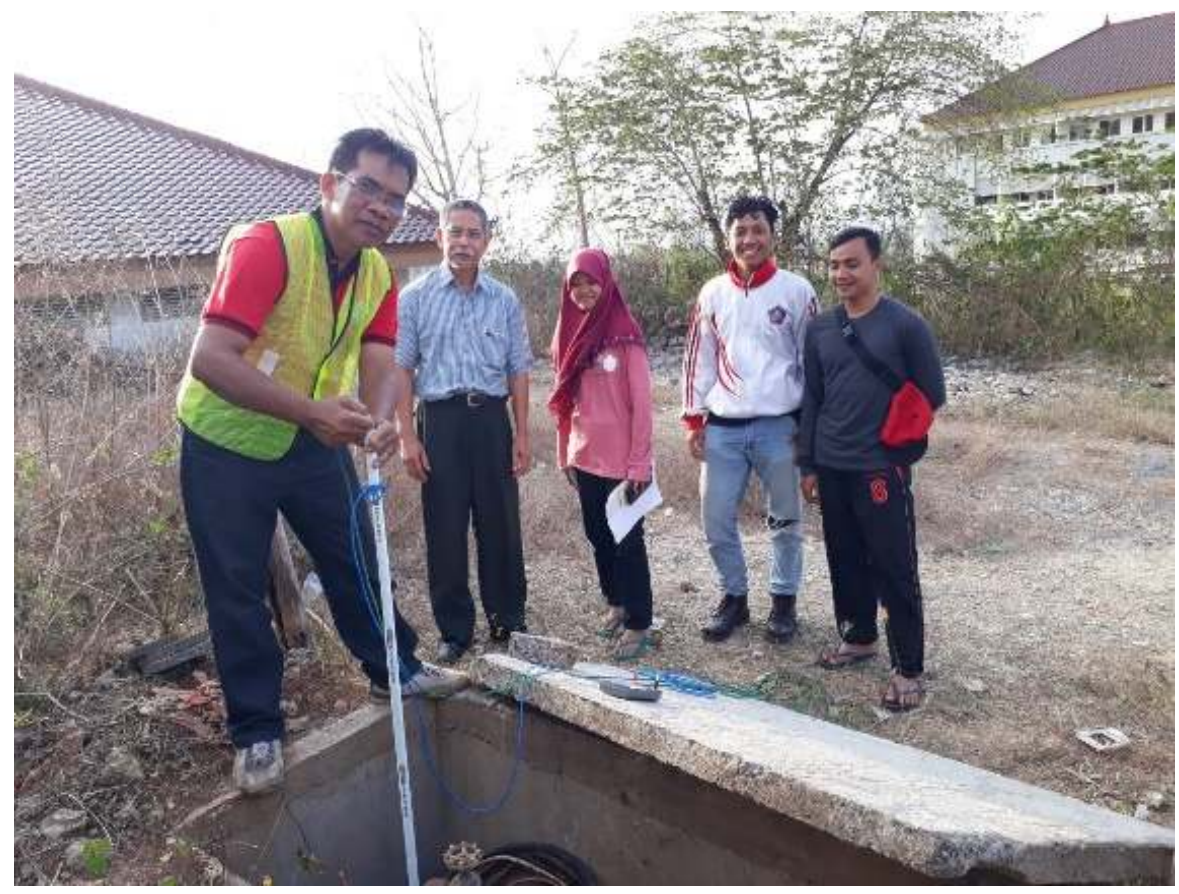

Gambar 5. Uji Sumur dengan Metode Step Drow Down Test 
Pelaksanaan uji pumping dilakukan dua jenis, yaitu dengan debit bertahap (Metode Step Drow Down Test) dan dengan debit tetap, memakai bak peluah bersudut $90^{\circ}$. Hasil pengukuran sebagai berikut.

Tabel 4. Data Hasil Penelitian dengan Debit Bertahap

$\begin{array}{ll}\text { Posisi sumur } & : \text { Jimbaran Bali } \\ \text { Lintang } & :-8,7912635 \\ \text { Bujur } & : 115,1737306 \\ \text { Ketinggian } & : 44 \mathrm{mdpl} \\ \text { Posisi ditemukan air } & : 42,75 \mathrm{~m} \\ \text { Kedalaman sumur } & : 51 \mathrm{~m} \\ \text { Cuaca } & : \text { Cerah } \\ \text { Hari/Tanggal pelaksanaan } & : \text { Rabu/11 Juli } 2018\end{array}$

\begin{tabular}{ccccc}
\hline No & Tahapan & Jam & Sw $(\mathrm{cm})$ & Ketinggian air $(\mathrm{h})(\mathrm{cm})$ \\
\hline 1 & 1 & 14.00 & 10,90 & 7,5 \\
2 & 1 & 14.15 & 10,90 & 7,5 \\
3 & 1 & 14.30 & 10,90 & 7,5 \\
4 & 1 & 14.45 & 10,90 & 7,5 \\
5 & 1 & 15.00 & 10,90 & 7,5 \\
6 & 2 & 15.05 & 12,25 & 8,0 \\
7 & 2 & 15.15 & 12,25 & 8,0 \\
8 & 2 & 15.30 & 12,25 & 8,0 \\
9 & 2 & 15.45 & 12,25 & 8,0 \\
10 & 2 & 16.00 & 12,25 & 8,0 \\
11 & 3 & 16.05 & 13,45 & 8,3 \\
12 & 3 & 16.15 & 13,45 & 8,3 \\
13 & 3 & 16.30 & 13,45 & 8,3 \\
14 & 3 & 16.45 & 13,45 & 8,3 \\
15 & 3 & 17.00 & 13,45 & 8,3 \\
16 & 4 & 17.05 & 15,45 & 8,5 \\
17 & 4 & 17.15 & 15,45 & 8,5 \\
18 & 4 & 17.30 & 15,45 & 8,5 \\
19 & 4 & 17.45 & 15,45 & 8,5 \\
20 & 4 & 18.00 & 15,45 & 8,5 \\
21 & 5 & 18.05 & 17,00 & 8,8 \\
22 & 5 & 18.15 & 17,00 & 8,8 \\
23 & 5 & 18.30 & 17,00 & 8,8 \\
24 & 5 & 18.45 & 17,00 & 8,8 \\
25 & 5 & 19.00 & 17,00 & 8,8 \\
\hline
\end{tabular}

\section{Keterangan:}

Sw: penurunan permukaan air dalam sumur setelah dilakukan uji pemompaan $\mathrm{h}$ : ketinggian air dalam bak peluah 
Tabel 5. Data Hasil Penelitian dengan Debit Tetap

Posisi sumur :Jimbaran Bali

Lintang :-8,7912635

Bujur : $: 115,1737306$

Ketinggian $\quad: 44 \mathrm{mdpl}$

Posisi ditemukan air $\quad: 42,75 \mathrm{~m}$

Kedalaman sumur $\quad: 51 \mathrm{~m}$

Cuaca : Cerah

Hari/Tanggal pelaksanaan Kabu/12 Juli 2018

\begin{tabular}{ccccc}
\hline No & Tahapan & Jam & Sw $(\mathrm{cm})$ & Ketinggian air $(\mathrm{h})(\mathrm{cm})$ \\
\hline 1 & 5 & 10.30 & 22,20 & 9,3 \\
2 & 5 & 11.00 & 22,20 & 9,3 \\
3 & 5 & 11.30 & 22,20 & 9,3 \\
4 & 5 & 12.00 & 22,20 & 9,3 \\
5 & 5 & 12.30 & 22,20 & 9,3 \\
6 & 5 & 13.00 & 22,20 & 9,3 \\
7 & 5 & 13.30 & 22,20 & 9,3 \\
8 & 5 & 14.00 & 22,20 & 9,3 \\
9 & 5 & 14.30 & 22,20 & 9,3 \\
10 & 5 & 15.00 & 22,20 & 9,3 \\
11 & 5 & 15.30 & 22,20 & 9,3 \\
12 & 5 & 16.00 & 22,20 & 9,3 \\
13 & 5 & 16.30 & 22,20 & 9,3 \\
14 & 5 & 17.00 & 22,20 & 9,3 \\
15 & 5 & 17.30 & 22,20 & 9,3 \\
16 & 5 & 18.00 & 22,20 & 9,3 \\
\hline
\end{tabular}

Keterangan:

Sw: penurunan permukaan air dalam sumur setelah dilakukan uji pemompaan

$\mathrm{h}$ : ketinggian air dalam bak peluah

\section{Analisa Data Uji Sumur}

Data pada Tabel 4 dapat direkap menjadi sebagai berikut:

Tabel 6. Data Rekapan Hasil Uji Sumur dengan Debit Bertahap

\begin{tabular}{|c|c|c|c|c|c|c|c|}
\hline \multirow[t]{2}{*}{ No } & \multirow[t]{2}{*}{ Tahapan } & \multirow[t]{2}{*}{ Jam } & \multirow[t]{2}{*}{$S_{w}(\mathrm{~m})$} & \multirow[t]{2}{*}{$\mathrm{h}(\mathrm{cm})$} & \multicolumn{3}{|c|}{$Q$} \\
\hline & & & & & Liter/detik & Liter/menit & $\mathrm{m}^{3} /$ detik \\
\hline 1 & 1 & 14.00 & 0,1090 & 7,5 & 2,14 & 128,48 & 0,00214 \\
\hline 2 & 2 & 15.05 & 0,1225 & 8,0 & 2,52 & 150,97 & 0,00252 \\
\hline 3 & 3 & 16.05 & 0,1345 & 8,3 & 2,76 & 165,54 & 0,00276 \\
\hline 4 & 4 & 17.05 & 0,1545 & 8,5 & 2,93 & 175,68 & 0,00293 \\
\hline 5 & 5 & 18.05 & 0,1700 & 8,8 & 3,19 & 191,58 & 0,00319 \\
\hline
\end{tabular}

Keterangan:

Sw: penurunan permukaan air dalam sumur setelah dilakukan uji pemompaan

$\mathrm{h}$ : ketinggian air dalam bak peluah

Q : debit pemompaan 
Menentukan persamaan susut sumur dengan regresi linier

\begin{tabular}{cccc}
\multicolumn{4}{c}{ Tabel 7. Perhitungan Susut Sumur } \\
\hline Tahapan & $\mathrm{Q}\left(\mathrm{m}^{3} / \mathrm{s}\right)$ & $\mathrm{S}_{\mathrm{w}}(\mathrm{m})$ & $\mathrm{S}_{\mathrm{w}} / \mathrm{Q}\left(\mathrm{s} / \mathrm{m}^{2}\right)$ \\
\hline 1 & 0,00214 & 0,1090 & 50,93 \\
2 & 0,00252 & 0,1225 & 48,61 \\
3 & 0,00276 & 0,1345 & 48,73 \\
4 & 0,00293 & 0,1545 & 52,73 \\
5 & 0,00319 & 0,1700 & 53,29 \\
\hline
\end{tabular}

Keterangan:

Sw: penurunan permukaan air dalam sumur setelah dilakukan uji pemompaan

Q : debit pemompaan

Berdasarkan Tabel 7 didapatkan persamaan susut sumur:

$$
\begin{aligned}
\mathrm{Sw} / \mathrm{Q} & =\mathrm{B}+\mathrm{CQ} \\
& =43,021+2894,2 \mathrm{Q}
\end{aligned}
$$

Ini berarti nilai $\mathrm{B}=43,021$ dan nilai $\mathrm{C}=2894,2$

\section{Mencari efesiensi sumur (Ew)}

Efesiensi sumur dicari dengan persamaan $\mathrm{Ew}=(\mathrm{BQ}) / \mathrm{Sw} \times 100 \%$, sehingga dapat dibuat tabel efesiensi sumur sebagai berikut:

Tabel 8. Perhitungan Efisiensi Sumur

Keterangan:

\begin{tabular}{cccccc}
\hline Tahapan & $\mathrm{Q}\left(\mathrm{m}^{3} / \mathrm{s}\right)$ & $\mathrm{Sw}(\mathrm{m})$ & $\mathrm{B}$ & $\mathrm{B} * \mathrm{Q}$ & $\mathrm{Ew}(\%)$ \\
\hline 1 & 0,00214 & 0,109 & 43,021 & 0,092065 & 84,46 \\
2 & 0,00252 & 0,1225 & 43,021 & 0,108413 & 88,50 \\
3 & 0,00276 & 0,1345 & 43,021 & 0,118738 & 88,28 \\
4 & 0,00293 & 0,1545 & 43,021 & 0,126052 & 81,59 \\
5 & 0,00319 & 0,17 & 43,021 & 0,137237 & 80,73 \\
\hline
\end{tabular}

Sw: penurunan permukaan air dalam sumur setelah dilakukan uji pemompaan

Q : debit pemompaan

Sc : kapasitas jenis sumur

Ew: efisiensi sumur

Efisiensi rata-rata (Ew rata-rata) menjadi 84,71\%, nilai ini sudah lebih besar dari 50\%, berarti sumur termasuk klasifikasi efisien.

\section{Mencari faktor pengembang sumur (Fd)}

Faktor pengembang didapatkan dengan cara: $(\mathrm{C} / \mathrm{B}) \times 100$, sehingga

$\mathrm{Fd}=(2894,2 / 43,021) \times 100=6727,4121 \mathrm{~s} / \mathrm{m}^{3}=0,077864 \mathrm{hari} / \mathrm{m}^{3}$ Ini berarti sumur sangat baik untuk dikembangkan.

\section{Mencari nilai perbaikan sumur (C)}

Berdasarkan persamaan susut sumur, nilai $\mathrm{C}=28994,2$, ini berarti sumurnya sulit dikembalikan menjadi seperti semula.

\section{Mencari kapasitas jenis sumur (Sc)}

Kapasitas jenis sumur (Sc) merupakan gambaran kasar yang menyatakan jumlah air diproduksi oleh sumur. Nilai ini tergantung dari debit pemompaan (Q) dan penurunan permukaan air $(\mathrm{Sw})$, yaitu: $\mathrm{Sc}=\mathrm{Q} / \mathrm{Sw}$, sehingga: 
Tabel 9. Perhitungan Kapasitas Jenis Sumur (Sc)

Keterangan:

\begin{tabular}{cccc}
\hline Tahapan & $\mathrm{Q}\left(\mathrm{m}^{3} / \mathrm{s}\right)$ & $S_{w}(\mathrm{~m})$ & $\mathrm{Sc}\left(\mathrm{m}^{2} / \mathrm{s}\right)$ \\
\hline 1 & 0,00214 & 0,1090 & 0,019633 \\
2 & 0,00252 & 0,1225 & 0,020571 \\
3 & 0,00276 & 0,1345 & 0,020520 \\
4 & 0,00293 & 0,1545 & 0,0189644 \\
5 & 0,00319 & 0,1700 & 0,0187647 \\
\hline \multicolumn{5}{r}{ Sc rata-rata } & & 0,0196908 \\
\hline
\end{tabular}

Sw: penurunan permukaan air dalam sumur setelah dilakukan uji pemompaan

Q : debit pemompaan

Sc : kapasitas jenis sumur

Kapasitas jenis (Sc) rata-rata didapat: $0,0196908 \mathrm{~m}^{2} / \mathrm{s}$, nilai ini lebih besar dari 0,005 . Ini berarti sumur memiliki produktifitas tinggi.

\section{Mencari debit optimum sumur ( $\left.Q_{\text {opt}}\right)$}

Langkah-langkah yang dilakukan untuk menentukan debit optimum sumur $\left(\mathrm{Q}_{\mathrm{opt}}\right)$ adalah sebagai berikut. Pertama mencari persamaan sumur dalam bentuk polinomial orde 2 berdasarkan data Q dan Sw seperti dalam Tabel 4. Hasilnya didapatkan

$$
y=62903 x^{2}-263,3 x+0,384
$$

$\mathrm{y}=\mathrm{Sw}=$ penurunan permukaan air

$\mathrm{X}=\mathrm{Q}=$ debit pemompaan

Dengan memasukkan parameter sumur seperti tabel berikut, maka dapat dihitung debit maksimum $\left(Q_{m a k s i)}\right.$ :

Tabel 10. Parameter Sumur Bor

\begin{tabular}{ll}
\hline \multicolumn{1}{c}{ Parameter } & \multicolumn{1}{c}{ Hasil } \\
\hline Kedalaman Sumur & $51 \mathrm{~m}$ \\
Jarak pompa dari dasar sumur & $0,5 \mathrm{~m}$ \\
Panjang pompa & $1 \mathrm{~m}$ \\
Posisi pompa & $49,5 \mathrm{~m}-50,5 \mathrm{~m}$ \\
Tinggi air diatas pompa minimal & $0,5 \mathrm{~m}$ \\
Drawdown maksimum $\left(\mathrm{S}_{\mathrm{w}}\right.$ maks $)$ & $6,25 \mathrm{~m}$ \\
\hline
\end{tabular}

$\mathrm{S}_{\mathrm{w} \text { maks }}=6,25 \mathrm{~m}$

Kedua menentukan Qmaks

$\mathrm{S}_{\mathrm{w} \text { maks }}=62903 \mathrm{x}^{2}-263,3 \mathrm{x}+0,384$

$6,25=62903 \mathrm{x}^{2}-263,3 \mathrm{x}+0,384$

$-62903 x^{2}-263,3 x+5,866=0$

$\mathrm{Q}_{1 \mathrm{maks}}=1,197 \cdot 10^{-2}$

$\mathrm{Q}_{2 \text { maks }}=-7,788 \cdot 10^{-2}$

$\mathrm{Q}_{\text {maks }}$ yang dipakai adalah yang bernilai positif $\left(\mathrm{Q}_{1 \mathrm{maks}}=1,197.10^{-2}\right)$

Debit optimum $\left(\mathrm{Q}_{\mathrm{opt}}\right)$ merupakan perpotongan antara grafik persamaan sumur dengan persamaan garis

$\mathrm{Q}_{\text {maks }}-\mathrm{Sw}_{\text {maks }}$ seperti pada gambar dibawah ini: 


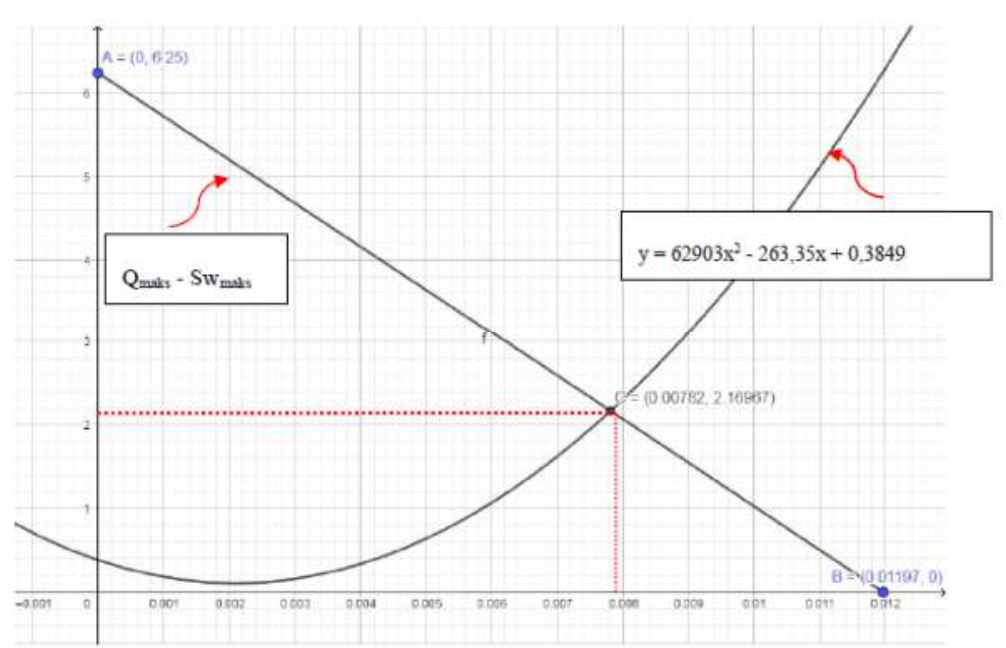

Gambar 6. Penentuan Debit Optimum (Q $\left.{ }_{\text {opt }}\right)$ Secara Grafik

Ketiga didapat debit optimum $\left(\mathrm{Q}_{\mathrm{opt}}\right)=0,00782 \mathrm{~m}^{3} / \mathrm{s}=28,152 \mathrm{~m}^{3} / \mathrm{jam}$. Drowdown optimum $\left(\mathrm{Sw}_{\mathrm{opt}}\right)=2,17 \mathrm{~m}$. Nampak bahwa adanya keterbatasan kuantitas cadangan air seperti yang dijelaskan oleh Cahyadi, dkk. ${ }^{1]}$

\section{Uji sumur dengan debit konstan}

Uji sumur dengan debit konstan $\left(0,00328 \mathrm{~m}^{3} / \mathrm{s}\right)$ telah dilakukan selama 7,5 jam (Tabel 2), ini berarti air sumur telah diambil $88,56 \mathrm{~m}^{3}$, tetapi sumur hanya mengalami penurunan permukaan air sebesar 22,2 $\mathrm{cm}$ secara konstan, yang berarti masih sisa drown optimum belum tercapai (sisa 194,8 cm) karena pengambilan airnya kurang dari debit optimum yang diperbolehkan (kurang dari 28,152 $\mathrm{m}^{3} / \mathrm{jam}$ ).

\section{KESIMPULAN}

Setelah dilakukan pengambilan data yang dilanjutkan dengan analisa data, maka dapat ditarik kesimpulan sebagai berikut. Secara umum karakteristik sumur dapat dikatakan bahwa walaupun sumur berada berada di daerah katu karang dan tandus, maka sumur sangat efesien untuk pengambilan air, baik untuk dikembangkan, sumur juga memiliki produktifitas tinggi. Hal ini karena dalam pembuatan sumur didapatkan akuifer pada titik pengeboran. Ada beberapa kelemahan sumur ini yaitu adanya keterbatasan kuantitas cadangan air, hanya sanggup dengan debit optimum $0,00782 \mathrm{~m}^{3} / \mathrm{s}=28,152 \mathrm{~m}^{3} / \mathrm{jam}$, apabila dalam jangka waktu panjang sumur mengalami masalah misalkan tiba-tiba debit airnya mengecil maka sumur tersebut sulit dikembalikan ke keadaan seperti semua.

\section{UCAPAN TERIMA KASIH}

Terima kasih kami ucapkan kepada tim pengambilan data yang terdiri dari Prof. Ir. I Wayan Redana, MA.Sc, Ph.D dan Ika Umratul Asni Aminy, S.Si atas supportnya sehingga pengambilan data dapat terselesaikan dengan baik walaupun sampai larut malam. Terima kasih juga kami ucapkan kepada Direktur RSPTN atas tempat yang diberikan untuk pengambilan data.

\section{DAFTAR PUSTAKA}

1 Cahyadi, A. \& Hidayat, W. 2017. Analisis Karakteristik Hidrogeokimia Airtanah di Pulau Koral Panggang, Kepulauan Seribu, DKI. Jakarta. Jurnal Geografi, Vol. 9, No. 2, Hal. 99-108. 
2 Cahyadi, A. 2012. Permasalahan Sumberdaya Air di Pulau Karang Sangat Kecil (Studi Kasus di Pulau Pramuka, Kabupaten Kepulauan Seribu, DKI Jakarta). Prosiding Seminar Nasional Pengelolaan Sumberdaya Alam dan Lingkungan. Semarang: Program Studi Ilmu Lingkungan Universitas Diponegoro.

3 Karunia, D.K., Darsono, \& Darmanto. 2012. Identifikasi Pola Aliran Sungai Bawah Tanah di Mudah, Pracimantoro dengan Metode Geolistrik. Indonesian Journal of Applied Physics. Vol. 2, No. 2, Hal. 91-101.

4 Simpen, I N \& I W. Redana. 2016. Pendugaan Posisi Akuifer dengan Metode Geolistrik dalam Rangka Membuat Sumur Bor di Villa Puri Persada Denpasar. Laboratorium Mekanika Tanah Jurusan Teknik Sipil Fakultas Teknik Universitas Udayana. Denpasar.

5 Luthfin,A., Husni Cahyadi, \& Jufri. 2020. Identifikasi Batuan Pondasi Candi (Andesit) di Bawah Permukaan Sekitar Candi Badut dengan Metode Geolistrik Resistivitas, Indonesian Journal of Applied Physics. Vol. 10, No. 2, Hal. 106-115.

6 Muhardi, Faurizal, \& Widodo. 2020. Analisis Pengaruh Intrusi Air Laut terhadap Keberadaan Air Tanah di Desa Nusapati, Kabupaten Mempawah Menggunakan Metode Geolistrik Resistivitas. Indonesian Journal of Applied Physics. Vol. 10, No. 2, Hal. 89-96.

7 Eddy Hartantyo, E. 2020. Vertical Electrical Sounding Analysis for Local Subsurface Water Bearing Identification Due to Isolated Hill. Case-study: Madurejo Village, Prambanan District, Yogyakarta Province, Indonesia. Indonesian Journal of Applied Physics. Vol. 10, No. 1, Hal. 50-55.

8 Susilo, A., Sunaryo, \& Fina Fitriah. 2018. Ground Investigation Using Resistivity Method and Drilling for Drought Mitigation in Tulungagung, Indonesia, International Journal of Geomate. Vol. 15, No. 47, Hal. 124-131.

9 Probo-Hadiwidjojo, M.M, H. Samodra \& T.C Amin. 1971. Peta Geologi Bali. Pusat Penelitian dan Pengembangan Geologi. Bandung.

10 Sudadi. P, H. Setiadi, BR Denny, Salahudin Arief, S. Ruchijat \& S. Adi, 1985, Peta Geohidrologi Indonesia Lembar Bali, Direktorat Tata Lingkungan Geologi dan Kawasan Pertambangan. Bandung.

11 Nudiana, Wayan \& Hendri Setiadi. 2008. Peta Sebaran Cekungan Air Tanah Pulau Bali. Departemen Energi dan Sumberdaya Mnineral Badan Geologi Pusat Lingkungan Geologi. Bandung.

12 Simpen, I N., I N. S. Sutama, I W. Redana, S. Zulaikah. 2015. Metode Step Drawdown Test Sebagai Cara Untuk Menganalisa Kemampuan Produksi Sumur. Prosiding Seminar Nasional Fisika. FMIPA Universitas Mataram-Lombok. Hal. 14-15.

13 Kruseman, G.P. and N.A. de Ridder. 1990. Analysis and Evaluation of Pumping Test Data. The Metherland.

14 Suharyadi. 1989. Studi Potensi Air Bawah Tanah-Dalam dan Kemungkinan Pengembangannya Sebagai Tambahan Air Irigasi di Sub DAS Opak, Daerah Istimew Yogyakarta (tesis). Fakultas Pasca Sarjana IPB. Bogor.

15 Untung Sudarsono. 1998. Prosedur Pompa Uji.Buletin Geologi Tata Lingkungan No. 23 Juni 1998.

16 Fauzie, M.J., M.M.Z. Azwan, C.M. Hasfalina \& T.A. Mohammed. 2014. Performance Evaluation and Characteristics of Selected Tube Walls in the Coastal Alluvium Aquifer, Selangor. Pertanica Science \& Technologi. Vol. 22, No. 1, Hal. 225-237. 